\title{
Growth and Enzymatic Activity of Four Warm- season Turfgrass Species Exposed to Waterlogging
}

\author{
Junqin Zong ${ }^{1}$, Yanzhi Gao${ }^{1}$, Jingbo Chen, Hailin Guo, Yi Wang, and Fan Meng \\ Institute of Botany, Jiangsu Province \& Chinese Academy of Sciences, 1 Qianhu Houcun, Nanjing \\ 210014, P.R. China \\ Yiwei Jiang ${ }^{2}$ \\ Department of Agronomy, Purdue University, 915 West State Street, West Lafayette, IN 47907 \\ Jianxiu Liu ${ }^{2}$ \\ Institute of Botany, Jiangsu Province \& Chinese Academy of Sciences, 1 Qianhu Houcun, Nanjing \\ 210014, P.R. China
}

\begin{abstract}
Additional INDEX wORDs. anaerobic metabolism, antioxidant, alcohol dehydrogenase, lactate dehydrogenase, superoxide dismutase, peroxidase

Abstract. Waterlogging (WL) negatively affects plant growth and development, but the physiological responses of turfgrass species to WL are not well understood. The objective of this study was to examine growth and physiological mechanisms of WL tolerance in warm-season turfgrass species. Knotgrass (Paspalum paspaloides), spiny mudgrass (Pseudoraphis spinescens), seashore paspalum (Paspalum vaginatum), and centipedegrass (Eremochloa ophiuroides) were subjected to 30 days of WL. At the end of the treatment, knotgrass and spiny mudgrass maintained the shoot and root biomass while seashore paspalum and centipedegrass showed reductions in biomass under WL. Root oxidase activity (ROA) was unaffected until after 12 or 18 days of WL but decreased by $14.3 \%, 17.8 \%, 32.0 \%$, and $68.7 \%$ at 30 days of WL for knotgrass, spiny mudgrass, seashore paspalum, and centipedegrass, respectively. Waterlogging increased root activities of lactate dehydrogenase and alcohol dehydrogenase, but generally to a lesser extent in knotgrass and spiny mudgrass. The leaf and root activities of superoxide dismutase (SOD) and peroxidase (POD) were induced after 6 or 12 days of WL, but to a greater extent for knotgrass and spiny mudgrass. At 30 days of WL, the increased leaf and root activities of SOD and POD were higher in knotgrass and spiny mudgrass than that of seashore paspalum and centipedegrass; while centipedegrass showed $37.8 \%$ reduction in root SOD activity. The total soluble protein (TSP) concentration remained unchanged in both leaves and roots during the entire WL treatment for knotgrass, while a decreased leaf TSP was found in the other three species after 12 or 24 days of WL as well as in the roots of seashore paspalum and centipedegrass. More reductions in leaf or root TSP were observed in seashore paspalum and centipedegrass than in knotgrass and spiny mudgrass at 30 days of WL. The results indicated that higher ROA, activities of antioxidant enzymes and TSP contributed to WL tolerance of warm-season turfgrass species.
\end{abstract}

Waterlogging is a common environmental stress that limits plant growth and development. Under waterlogging conditions, soil pores are filled with water and hypoxia often occurs, thereby hindering the exchange of $\mathrm{O}_{2}$ and other gases between roots and the atmospheric environment (Armstrong, 1979). Oxygen deficiency is one of the primary root stresses in the waterlogged or flooded soils (Kozlowski, 1984). As a result, plant metabolism at various growth stages can be significantly affected due to lack of oxygen supply in the environment (Colmer and Voesenek, 2009).

In a water excess environment, one of the fundamental physiological alterations is waterlogged or flood-induced anaerobic respiratory pathways. In the absence of oxygen, roots rely on anaerobic respiration pathways to produce limited energy to maintain metabolic activity (Bailey-Serres and Voesenek, 2008). Thus, adaptation of roots to flooding stress

Received for publication 10 Nov. 2014. Accepted for publication 30 Jan. 2015. This work was financially supported by the National Science and Technology Major Project of the Ministry of Science and Technology of China (Project No. 2012ZX 07101) and the Water Conservancy Projects of Jiangsu Province (Grant Nos. 2011076 and 2014001)

${ }^{1}$ These authors contributed equally to this work.

${ }^{2}$ Corresponding author. E-mail: yjiang@purdue.edu or turfunit@aliyun.com. is critical to whole-plant survival. Compared with flood sensitive species, flood tolerant species are better able to regulate their processes of glycolysis and fermentation to ethanol (Drew, 1997). However, depending on the species and duration of stress, alterations of anaerobic enzyme activity are not always consistent with waterlogging tolerance. The increased alcohol dehydrogenase (ADH) or lactate dehydrogenase (LDH) under waterlogging can be found in the tolerant and sensitive cultivars of a plant species (KatoNoguchi and Morokuma, 2007; Wei et al., 2013; Yin et al., $2009,2010)$. ADH and LDH activities were enhanced in the roots of a flood tolerant cultivar of sorghum (Sorghum bicolor) during $72 \mathrm{~h}$ of flooding but a transient increase in the activities was found in the roots of a flood sensitive cultivar up to $24 \mathrm{~h}$ flooding followed by a decline in activities of these enzymes (Jain et al., 2010). In addition, plant species vary in their selection of anaerobic respiration pathways for survival of flood stress. Flood tolerant Dendranthema zawadskii showed higher root ADH activities in favor of ethanol fermentation, whereas flood sensitive Dendranthema nankingense preferred lactic acid fermentation as a main way of anaerobic respiration (Yin et al., 2010). The ethanol produced by anaerobic respiration is composed of neutral molecules 
that can diffuse and may have a smaller negative effect on plants (Kato, 2000). Moreover, lactic acid fermentation produces high amounts of lactic acid, leading to cytoplasmic acidification, which may not be a long-term survival strategy of plants under stress. Collectively, responses of anaerobic enzymes to waterlogging stress can be influenced by the plant species, duration, and intensity of the stress. Their roles in waterlogging tolerance are not fully understood, especially for perennial grass species exposed to a relatively longer period of stress.

Waterlogging stress can block the chloroplast and mitochondrial electron transport chain inside the plant cell and cause decreases in cell energy charge and increases in the reducing power. As a result, production of active oxygen species (ROS) such as superoxide $\left(\mathrm{O}^{2-}\right)$ and hydrogen peroxide $\left(\mathrm{H}_{2} \mathrm{O}_{2}\right)$, hydroxyl radical $\left(\mathrm{OH}^{-}\right)$, and singlet oxygen is enhanced, which can break cell homeostasis and is detrimental to the plant cell (Mittler, 2002). Plants have evolved defense systems to protect cells against oxidative injury by removing, decomposing or scavenging ROS. Antioxidant metabolisms play an important role in detoxification of ROS (Mittler, 2002). By de novo sequencing, assembly, and analysis of the roots and shoots transcriptome in response to short-term waterlogging, Qi et al. (2014) concluded that ROS detoxification and energy maintenance were the primary coping mechanisms of 'Zhongshansa', a hybrid of baldcypress (Taxodium distichum) and montezuma cypress (Taxodium mucronatum) in surviving waterlogging. In enzymatic defense systems, SOD plays a central role in catalyzing the dismutation of $\mathrm{O}_{2}{ }^{-\cdot}$ to $\mathrm{H}_{2} \mathrm{O}_{2}$ and $\mathrm{O}_{2}$ (Bowler et al., 1992). In creeping bentgrass (Agrostis stolonifera), SOD activities in the roots increased $83 \%$ and $44 \%$ in the waterlogging tolerant 'PennG-6' and increased $32 \%$ and $26 \%$ for intolerant 'Penncross' when waterlogging occurred at 15 and $1 \mathrm{~cm}$ below soil level, respectively (Wang and Jiang, 2007). The decreased and unchanged SOD activities as well as differential responses of other antioxidant enzymes such as catalase (CAT), POD, and ascorbate peroxidase (APX) to waterlogging or submergence have also been found in different plant species (Ahmed et al., 2002; Arbona et al., 2008; Lin et al., 2004; Tan et al., 2010; Wang and Jiang, 2007). In addition, significant correlations between SOD and APX and between SOD and CAT were observed in the waterlogging tolerant citrus genotype 'Carrizo' citrange (Poncirus trifoliata $\times$ Citrus sinensis), supporting the idea of synergistic action in the positive antioxidant response (Arbona et al., 2008). Similar to anaerobic metabolism, differential responses of antioxidant enzymes to waterlogging vary with species and stress duration and intensity. The enhanced activity of antioxidant enzymes during waterlogging stress could contribute to waterlogging tolerance in the tolerant cultivar; however, responses of antioxidant enzymes to waterlogging tolerance are not fully understood, especially for warm-season turfgrasses.

Turfgrasses are often subjected to water excess environments due to frequent, heavy rainfall or over-irrigation followed by slow drainage. Although growth and physiological responses to waterlogging or submergence have been investigated in cool-season turfgrass species (Jiang and Wang, 2006; Wang and Jiang, 2007; Yu et al., 2012), alterations in growth and anaerobic and antioxidant enzymatic activities are
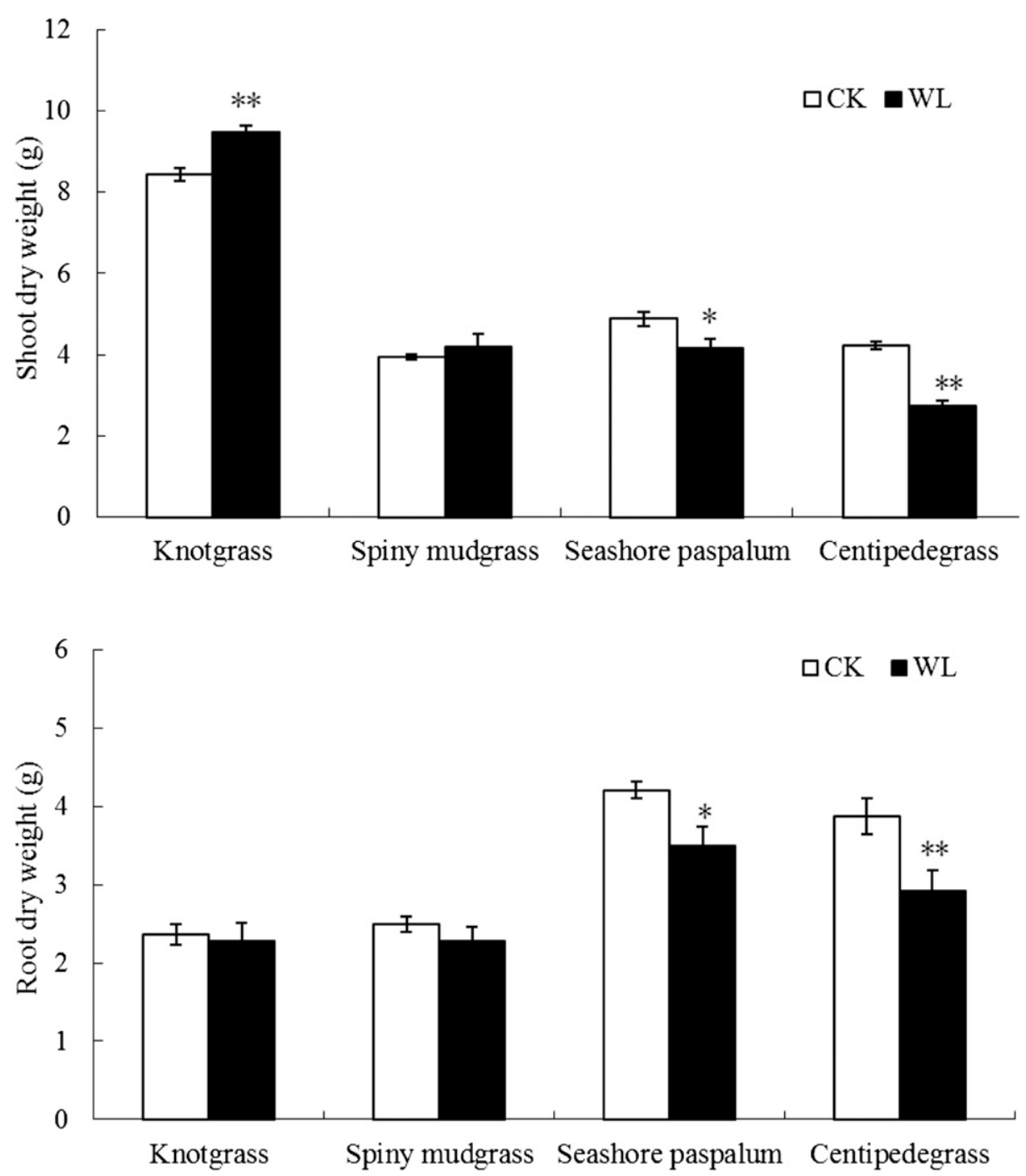

Fig. 1. Shoot and root biomass as affected by $30 \mathrm{~d}$ of waterlogging in knotgrass, spiny mudgrass, seashore paspalum, and centipedegrass. Comparisons are made between the control (CK) and waterlogging (WL) for each species. Values for each species for a given treatment averaged by three replications; * and ** indicate significant differences at $P<0.05$ and $<0.01$, respectively. 
not well understood in perennial grasses under waterlogging stress, especially for warm-season turf species under an extended period of waterlogging. Therefore, the specific objectives of this study were to determine growth response of four warm-season turfgrass species exposed to waterlogging stress and to examine anaerobic and antioxidant metabolism in relation to waterlogging tolerance. The outcome of this study would provide a basis for selecting appropriate species for turfgrass sites adjacent to flood plains or for vegetation restoration.

\section{Materials and Methods}

Plant materials and growing Conditions. The experiment was conducted in a greenhouse in the Grass Research Center at the Institute of Botany, Jiangsu Province and Chinese Academy
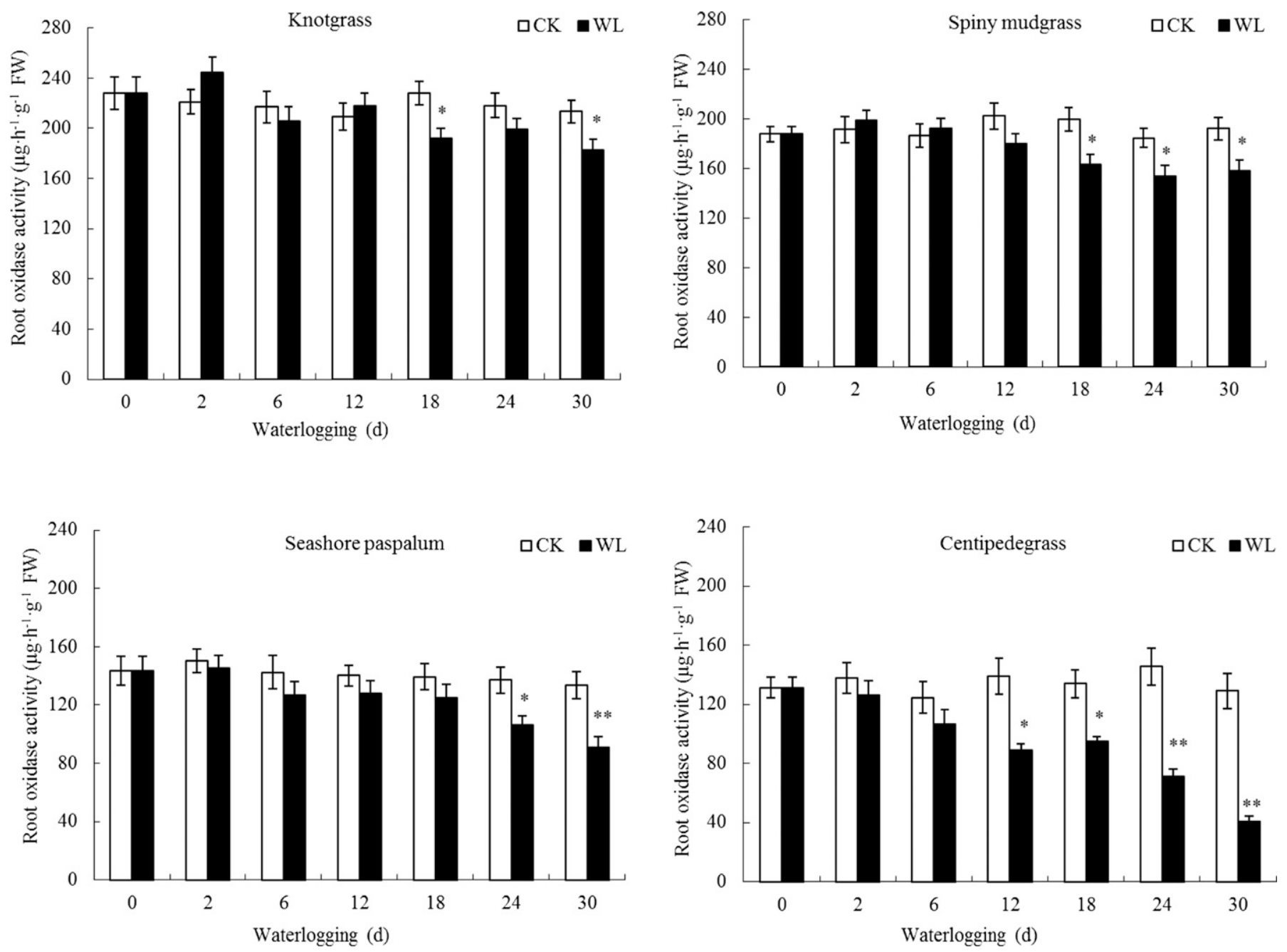

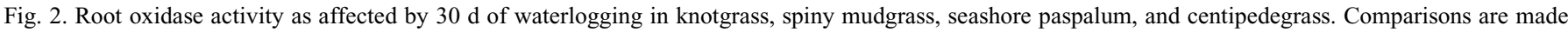
between the control (CK) and waterlogging (WL) under each day of treatment for a given species. Values for each date for a given treatment averaged by three replications; * and ** indicate significant differences at $P<0.05$ and $<0.01$, respectively.

Table 1. The percentage reduction or increase in root oxidase activity (ROA), activities of root lactate dehydrogenase (LDH), root alcohol dehydrogenase (ADH), leaf superoxide dismutase (LSOD), root superoxide dismutase (RSOD), leaf peroxidase (LPOD), root peroxidase (RPOD), leaf total soluble protein concentration (LTSP), and root total soluble protein concentration (RTSP) for four turfgrass species under $30 \mathrm{~d}$ of waterlogging compared with grasses under control conditions.

\begin{tabular}{|c|c|c|c|c|c|c|c|c|c|}
\hline \multirow[b]{2}{*}{ Species } & \multicolumn{9}{|c|}{ Percentage reduction $(-)$ or increase $(+)$} \\
\hline & $\mathrm{ROA}(-)$ & $\mathrm{LDH}(+)$ & $\mathrm{ADH}(+)$ & $\operatorname{LSOD}(+)$ & RSOD (+) & LPOD $(+)$ & RPOD (+) & $\operatorname{LTSP}(-)$ & $\operatorname{RTSP}(-)$ \\
\hline Knotgrass & $14.3 \mathrm{~d}$ & $8.5 \mathrm{a}$ & $26.0 \mathrm{c}$ & $140.0 \mathrm{a}$ & $46.8 \mathrm{a}$ & $153 \mathrm{a}$ & $76.3 \mathrm{~b}$ & $4.7 \mathrm{~d}$ & $7.8 \mathrm{~b}$ \\
\hline Spiny mudgrass & $17.8 \mathrm{c}$ & $14.3 \mathrm{a}$ & $15.7 \mathrm{c}$ & $87.0 \mathrm{~b}$ & $39.9 \mathrm{~b}$ & $91.5 \mathrm{~b}$ & $118 \mathrm{a}$ & $25.0 \mathrm{c}$ & $4.1 \mathrm{~b}$ \\
\hline Centipedegrass & $68.7 \mathrm{a}$ & 16.5 c (-) & $207 \mathrm{a}$ & $11.1 \mathrm{~d}$ & $37.8 \mathrm{~d}(-)$ & $84.7 \mathrm{~d}$ & $14.3 \mathrm{~d}$ & $36.5 \mathrm{a}$ & $29.7 \mathrm{a}$ \\
\hline
\end{tabular}


of Sciences. Four species of knotgrass, spiny mudgrass, seashore paspalum, and centipedegrass, varying with submergence tolerance (Gao et al., 2014), were used in this study. On 18 May 2013, 30 stolon segments of each species at the same growth stages were planted in plastic pots $(12 \mathrm{~cm}$ height, $14 \mathrm{~cm}$ diameter) containing sand and soil (1:4 mix). Forty-two pots of each species were grown for 2 months. During the growth period, samples were cut once every $10 \mathrm{~d}$. Based on the growth characteristics of the different grass species, cutting heights were $5 \mathrm{~cm}$ for seashore paspalum and centipedegrass and $10 \mathrm{~cm}$ for knotgrass and spiny mudgrass. Trimming was stopped when the waterlogging treatment started. During the experiment, the average day air temperatures was $28{ }^{\circ} \mathrm{C}$ and maximum photosynthetic photon flux density was $1700 \mu \mathrm{mol} \cdot \mathrm{m}^{-2} \cdot \mathrm{s}^{-1}$ in the greenhouse, with $14 \mathrm{~h}$ of natural light.

Waterlogging TREATMENT. Waterlogging treatment started when plant tissue coverage was more than $80 \%$ for all species. The waterlogging treatment began on 20 July 2013 and lasted for $30 \mathrm{~d}$. The pots were placed into barrels $(24 \mathrm{~cm}$ tall, $29 \mathrm{~cm}$ diameter) containing distilled water. Since the pots had drainage holes, the distilled water got into the pots with soil and the roots were exposed to the distilled water. The distilled water was a stress to the plants (Pearson and Kirkham, 1981), which could affect the responses of plants to waterlogging. The water level was $2-3 \mathrm{~cm}$ higher than the soil surface of the pots. To compensate for water loss caused by evapotranspiration, water was added every $3 \mathrm{~d}$ to maintain the water level in the barrels. The water was replaced every $5 \mathrm{~d}$, and algae were removed if accumulated to maintain transparency of the water. The control plants were well-watered without soil saturation.

Sampling and measurements. Samplings for leaves and roots were made at $0,2,6,12,18,24$, and $30 \mathrm{~d}$ of waterlogging for enzyme assay. At each day, three pots of the control and three waterlogged pots were removed from their respective containers. The fully developed leaves were harvested and roots were washed free of soil. The fresh leaves and roots were immediately used for enzyme assay. At the end of treatment $(30 \mathrm{~d})$, shoots and roots were harvested and the dry weight was determined.

Root oxidase activity was used to indicate vigor of the roots. The measurement of ROA was conducted with $1 \mathrm{~g}$ fresh roots using the $\alpha$-naphthylamine method (Li, 2000). For extraction of $\mathrm{LDH}$ and $\mathrm{ADH}, \approx 0.5 \mathrm{~g}$ roots were placed into a precooled mortar and ground in an ice bath with a precooled enzyme extract containing $1.6 \mathrm{~mL}$ of $5 \mathrm{~mm} \mathrm{MgCl}_{2}, 5 \mathrm{~mm} \beta$-mercaptoethanol, $15 \%$ glycerol, $1 \mathrm{~mm}$ EDTA, $1 \mathrm{~mm}$ EGTA, with $0.1 \mathrm{~mm}$
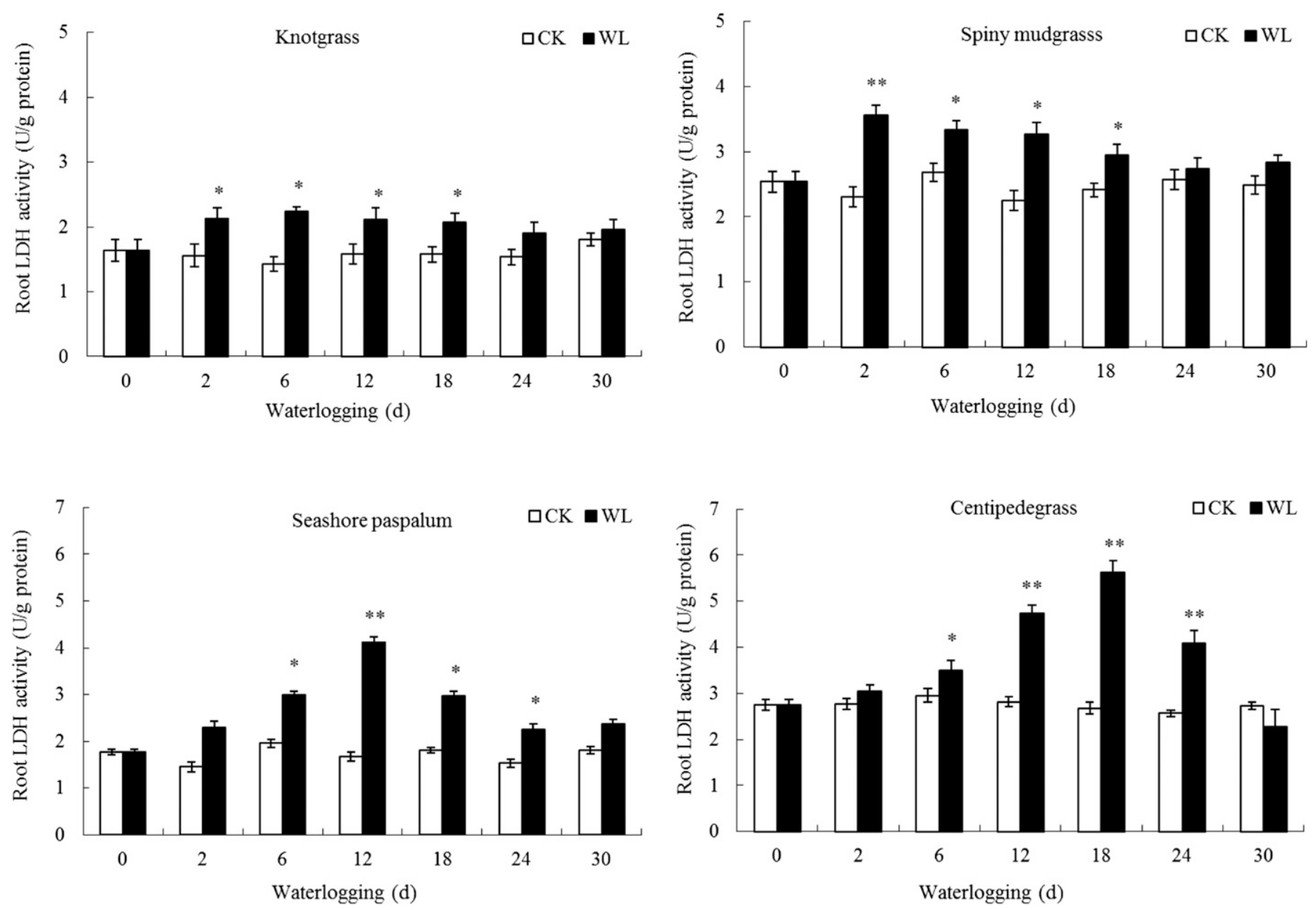

Fig. 3. Root activity of lactate dehydrogenase (LDH) as affected by $30 \mathrm{~d}$ of waterlogging in in knotgrass, spiny mudgrass, seashore paspalum, and centipedegrass. Comparisons are made between the control (CK) and waterlogging (WL) under each day of treatment for a given species. Values for each date for a given treatment averaged by three replications; * and ** indicate significant differences at $P<0.05$ and $<0.01$, respectively. 
phenylmethylsulfonyl fluoride added. The mixture was centrifuged at $12000 \mathrm{~g}_{\mathrm{n}}$ for $20 \mathrm{~min}$ at $4{ }^{\circ} \mathrm{C}$ and the supernatant was collected. Activities of both $\mathrm{LDH}$ and $\mathrm{ADH}$ were measured with the kit (A020-1 and A083; Nanjing Jiancheng Bioengineering Institute, Nanjing, P.R. China) at wavelengths of $440 \mathrm{~nm}$ for $\mathrm{LDH}$ and $340 \mathrm{~nm}$ for $\mathrm{ADH}$. The rate of $1 \mu \mathrm{mol}$ substrate reduced per minute was obtained as a unit of enzyme activity (U), and the enzyme activity was expressed in $U$ per gram protein. The protein content was determined using Bradford's method (Bradford, 1976).

For extraction of the antioxidant enzyme, up to $0.2 \mathrm{~g}$ leaves and $0.5 \mathrm{~g}$ roots were ground with $4 \mathrm{~mL}$ of precooled phosphate buffer solution ( $\mathrm{pH} 7.8)$. The mixture was centrifuged for $20 \mathrm{~min}$ at $4000 \mathrm{~g}_{\mathrm{n}}$, and the supernatant was collected. SOD activity was measured by recording the rate of p-nitro blue tetrazolium chloride (NBT) reduction in absorbance at $560 \mathrm{~nm}$ (Giannopolities and Rise, 1977). The $3-\mathrm{mL}$ reaction contained $1.5 \mathrm{~mL}$ of $50 \mathrm{~mm}$ phosphate buffer solution, $0.3 \mathrm{~mL}$ of $130 \mu \mathrm{M}$ methionine solution, $0.3 \mathrm{~mL}$ of $750 \mu \mathrm{M}$ NBT solution, $0.3 \mathrm{~mL}$ of $100 \mu \mathrm{M}$ EDTA-Na solution, $0.3 \mathrm{~mL}$ of $20 \mu \mathrm{M}$ riboflavin solution, $0.05 \mathrm{~mL}$ of enzyme, and $0.25 \mathrm{~mL}$ of distilled water. The mixture was illuminated under $60-70 \mu \mathrm{mol} \cdot \mathrm{m}^{-2} \cdot \mathrm{s}^{-1}$ for $20 \mathrm{~min}$. The reaction mixture lacking the enzyme developed maximum color as maximum reduction of NBT. The additional reaction mixture serving as the control was placed in the dark. One unit of SOD activity was defined as the amount of enzyme that caused $50 \%$ inhibition in the rate of NBT reduction. POD activity was measured by the guaiacol method (Li, 2000). A $0.1-\mathrm{mL}$ aliquot of the supernatant was added to the reaction mixture containing $2.9 \mathrm{~mL}$ of $50 \mathrm{~mm}$ phosphate buffer $(\mathrm{pH}$ $5.5), 1.0 \mathrm{~mL}$ of $2 \%$ hydrogen peroxide, and $1.0 \mathrm{~mL}$ of $50 \mathrm{~mm}$ guaiacol, and compared with phosphate buffer without enzyme. The absorbance was read every $30 \mathrm{~s}$ at the wavelength of $470 \mathrm{~nm}$ for $3 \mathrm{~min}$. The enzyme activity was calculated based on unit change per minute.

Data Analysis. The experiment was arranged in a completely randomized design with three replicates for the control and waterlogging treatments for each species. Data were analyzed using SAS (version 9.1; SAS Institute, Cary, NC). The means of the treatments were separated using least significant difference (LSD) at a 0.05 significance level.

\section{Results and Discussion}

Analysis of variance indicated that treatment and accession all had significant effects on all parameters. Significant WL by species interactions also were shown in all parameters (data not shown).

EfFects of WATERLogging on Biomass. Compared with the control, WL at $30 \mathrm{~d}$ significantly increased shoot dry weight (SDW) of knotgrass and did not change SDW of spiny
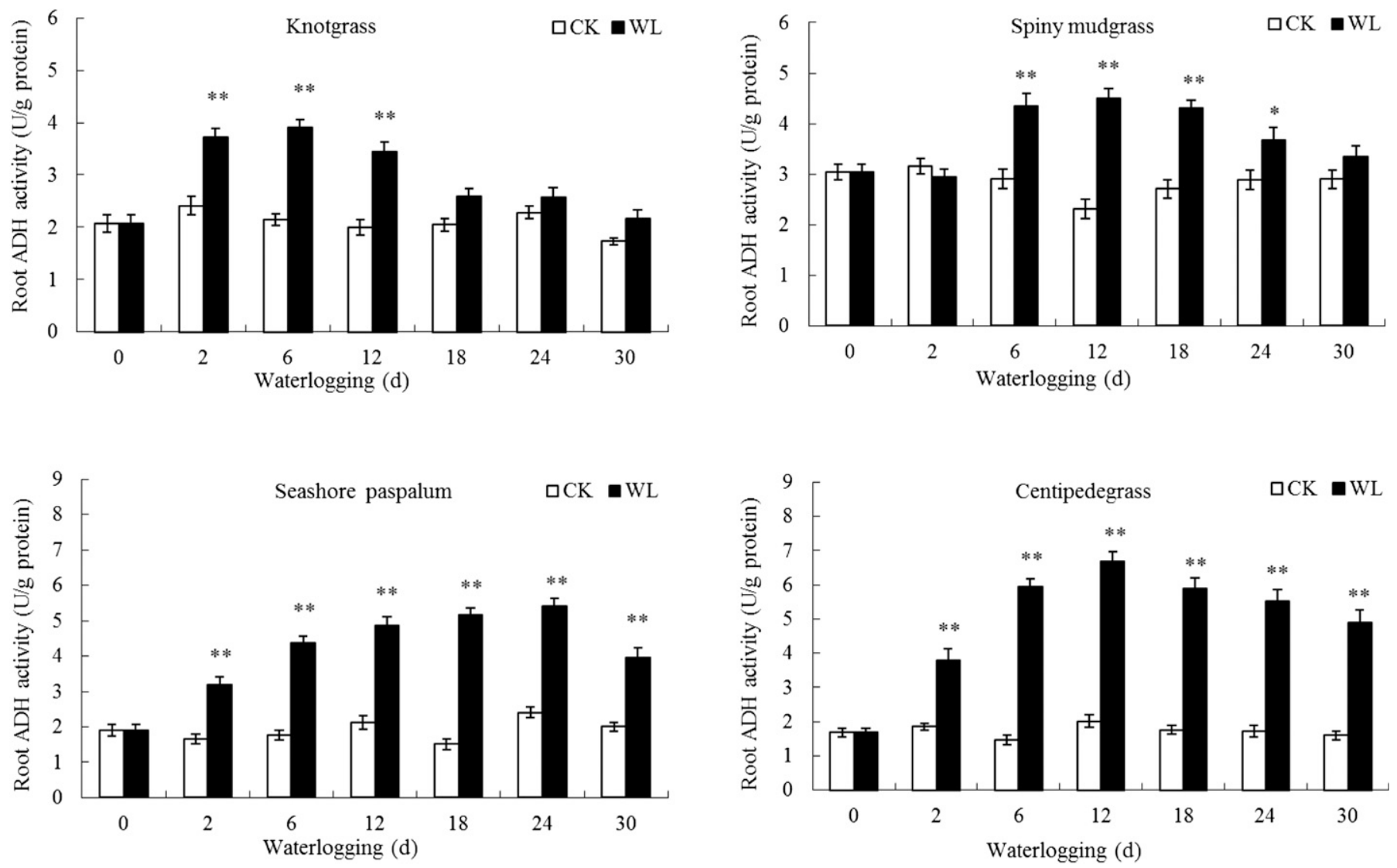

Fig. 4. Root activity of alcohol dehydrogenase (ADH) as affected by $30 \mathrm{~d}$ of waterlogging in knotgrass, spiny mudgrass, seashore paspalum, and centipedegrass. Comparisons are made between the control (CK) and waterlogging (WL) under each day of treatment for a given species. Values for each date for a given treatment averaged by three replications; * and ** indicate significant differences at $P<0.05$ and $<0.01$, respectively. 
mudgrass but decreased SDW of seashore paspalum and centipedegrass (Fig. 1). The root dry weight (RDW) was unaffected by $30 \mathrm{~d}$ of WL for knotgrass and spiny mudgrass but RDW was reduced in seashore paspalum and centipedegrass (Fig. 1). The SDW and RDW was $112 \%$ and $96 \%$ for knotgrass, $107 \%$ and $92 \%$ for spiny mudgrass, $86 \%$ and $83 \%$ for seashore paspalum, $65 \%$ and $75 \%$ for centipedegrass, respectively. Decreased RDW were also found in cool-season kentucky bluegrass (Poa pratensis) and creeping bentgrass exposed to waterlogging stress with more reductions in RDW observed in the intolerant cultivar (Jiang and Wang, 2006; Wang and Jiang, 2007). Our findings in the current study of four warm-season turfgrass species were consistent with the results in cool-season turfgrass study. The increased biomass in knotgrass under WL conditions indicated that WL simulated growth of this species. The simulated growth was also found in some accessions of perennial ryegrass exposed to submergence (Yu et al., 2012). Hormones such as ethylene and gibberellic acid could play a role in regulating plant growth under waterlogged soil (Jackson, 1985). The differential responses of growth to waterlogging could be also associated with other metabolic changes of the plants such as anaerobic and antioxidant metabolism (Wang and Jiang, 2007; Wang et al., 2009).
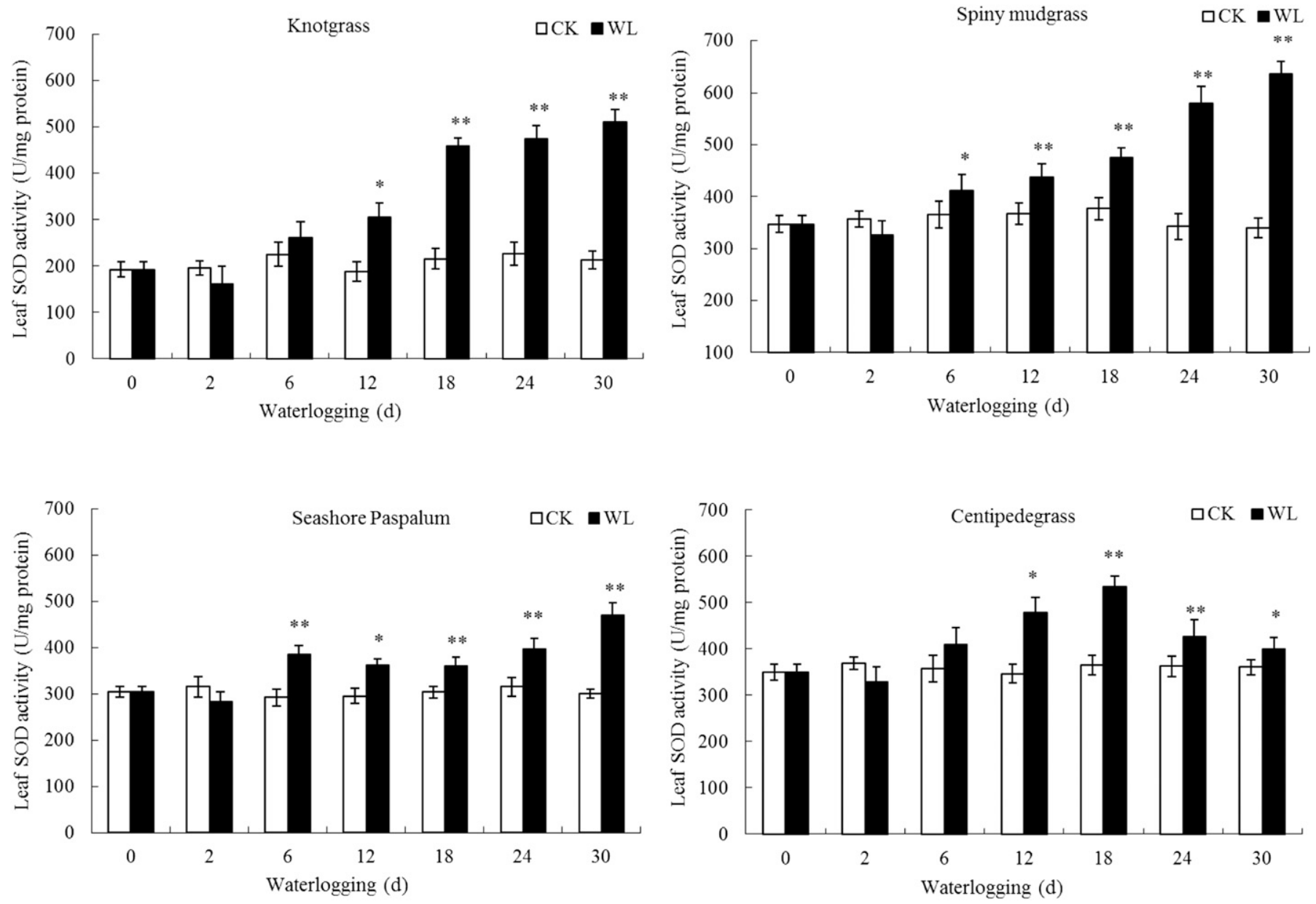

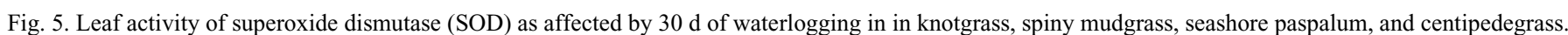
Comparisons are made between the control (CK) and waterlogging (WL) under each day of treatment for a given species. Values for each date for a given treatment averaged by three replications; $*$ and ** indicate significant differences at $P<0.05$ and $<0.01$, respectively. 
seashore paspalum and centipedegrass (Fig. 3). The maximum increased LDH activities during WL treatment were $57.3 \%, 54.0 \%, 1.5$ - and 1.1-fold higher than the control for knotgrass, spiny mudgrass, seashore paspalum, and centipedegrass, respectively (Fig. 3). At $30 \mathrm{~d}$, LDH activities under WL conditions returned to the control level for all species; however, four species differed significantly in percentage reduction or increase in root $\mathrm{LDH}$ activities (Fig. 3, Table 1).

Enhanced root activities of $\mathrm{ADH}$ were also noted in the four species (Fig. 4). Compared with the control, $\mathrm{ADH}$ activities increased after $2 \mathrm{~d}$ of WL for all species except for spiny mudgrass, whereas its ADH activity increased after $6 \mathrm{~d}$ of WL (Fig. 4). The increased ADH activities lasted for $10 \mathrm{~d}$ for knotgrass, $18 \mathrm{~d}$ for spiny mudgrass, and $28 \mathrm{~d}$ for both seashore paspalum and centipedegrass. The maximum increased ADH activities during WL were $81.9 \%$ for knotgrass, $95.2 \%$ for spiny mudgrass, and 2.4 -fold for both seashore paspalum and centipedegrass, compared with the control. Unlike knotgrass and spiny mudgrass, ADH activities were still higher than the control in both seashore paspalum and centipedegrass at the end of the WL treatment. Compared with the control, the percentage increases in ADH under $30 \mathrm{~d}$ of WL were significantly higher in centipedegrass and seashore paspalum than in knotgrass and spiny mudgrass (Table 1).

Root anaerobic metabolism plays an important role in producing energy for the short-term survival of plants in anaerobic environments through fermentative metabolism (Drew, 1997; Richard et al., 2006), which involves several key enzymes including ADH and LDH. Compared with flood sensitive species, flood tolerant species are better able to regulate their processes of glycolysis and fermentation to ethanol (Drew, 1997). Waterlogging stress or submergence induces $\mathrm{ADH}$ and $\mathrm{LDH}$ activities in plant species (Chen and Qualls, 2003; Wang et al., 2009; Yin et al., 2009); however, the results are often inconsistent when comparing the anaerobic responses of the tolerant and sensitive species and cultivars to stress. The activities or expressions of these anaerobic enzymes exhibit different patterns under various flooding stresses. In rice (Oryza sativa), the short-term anoxic stress did not change LDH activity or lactate concentration but increased $\mathrm{ADH}$ and pyruvate decarboxylase (PDC) activities as well as ethanol concentration in the coleoptiles of four cultivars, to a greater extent in the two cultivars with more coleoptile elongation (Kato-Noguchi and Morokuma, 2007). The results of that study suggest that the ability to increase ethanolic fermentation may be one of the determinants in
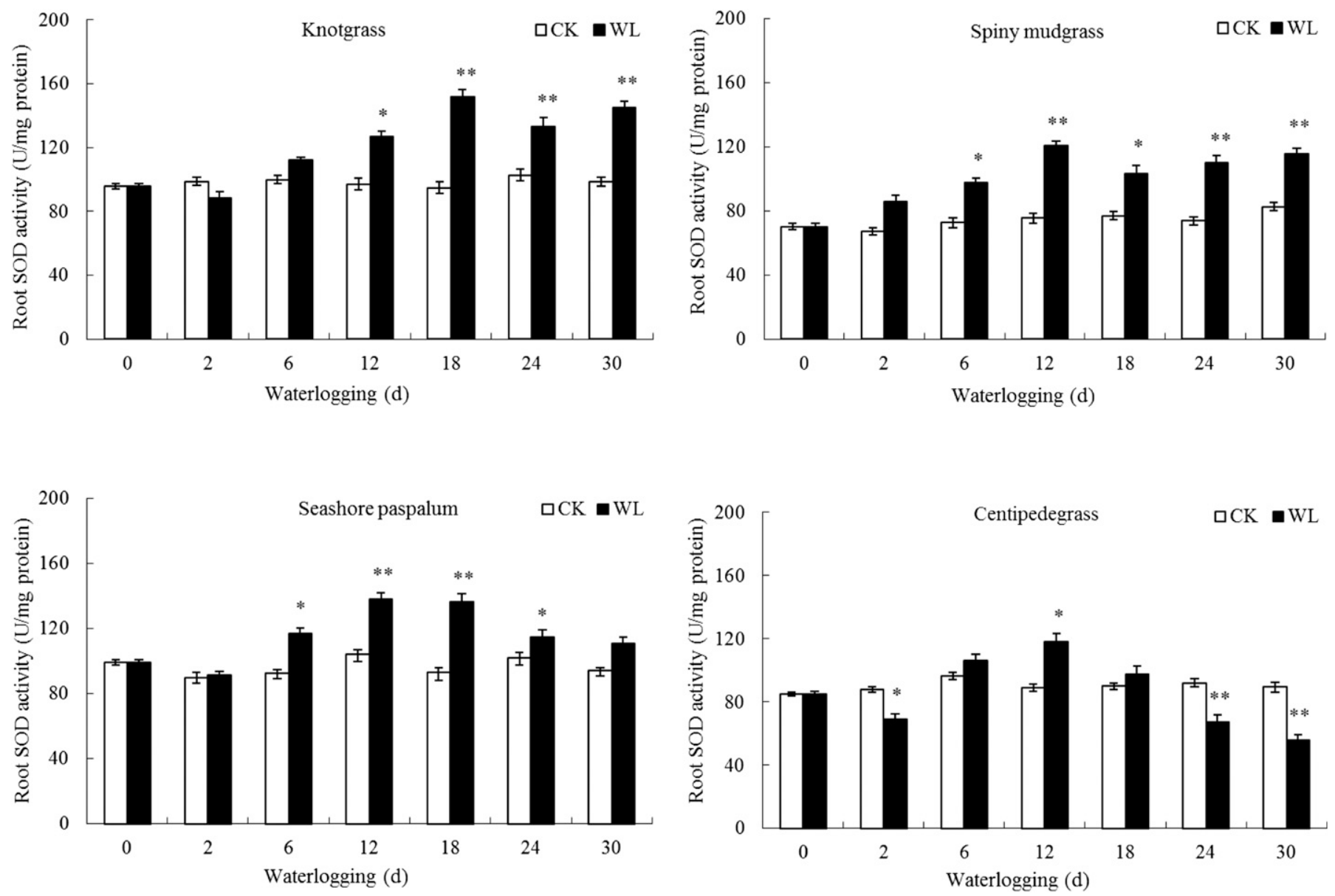

Fig. 6. Root activity of superoxide dismutase (SOD) as affected by $30 \mathrm{~d}$ of waterlogging in knotgrass, spiny mudgrass, seashore paspalum, and centipedegrass. Comparisons are made between the control (CK) and waterlogging (WL) under each day of treatment for a given species. Values for each date for a given treatment averaged by three replications; * and ** indicate significant differences at $P<0.05$ and $<0.01$, respectively. 
anoxia tolerance of rice coleoptiles under short-term stress. In another study, activities of ADH and LDH increased in the roots of sesame (Sesamum indicum), but ADH activity was higher in the tolerant cultivar and LDH activity was higher in the intolerant cultivar (Wei et al., 2013). Enhanced ADH and LDH activities were also found in chrysanthemum (Dendranthema grandiflorum), but to a greater extent in the waterlogging sensitive cultivar (Yin et al., 2009). Our results supported these observations found in chrysanthemum, with more pronounced $\mathrm{ADH}$ and $\mathrm{LDH}$ activities noted in the intolerant seashore paspalum and centipedegrass. The results indicate a stronger root ethanol fermentation in the waterlogging sensitive grass species exposed to a longer period of stress. The enhanced anaerobic respiration could result in accumulation of anaerobic respiration products (e.g., lactic acid and ethanol), which may cause a metabolism disturbance of cells in the roots and influence the function of normal cells (Drew, 1983). This might be one of the factors causing the reduced growth and poor waterlogging tolerance of seashore paspalum and centipedegrass in this study. Furthermore, maize (Zea mays) and barley (Hordeum vulgare) mutants lacking the ADH1 gene became more sensitive to flooding injury than the wild type plants (Roberts et al., 1989), suggesting a role of ADH in flooding tolerance.
However, strong over-expression of LDH and ADH had no effect on improving survival under low oxygen stress in Arabidopsis thaliana, whereas over-expression of PDC enhanced survival (Ismond et al., 2003). All the results suggest that species variation and duration of stress influence anaerobic metabolism and waterlogging tolerance. The anaerobic responses in the four warm-season turfgrass species found in this study indicate that low sensitivity of fermentation pathway to waterlogging may be associated with waterlogging tolerance in some perennial grass species.

Activities of ANTIOXIDANT ENZYMe. The activities of antioxidant enzymes in response to waterlogging conditions have been investigated in plant species; however, the results are often inconsistent. In this study, WL increased SOD activities in both leaves and roots, varying with stress duration and species. In the leaves, the increased SOD activities were shown at $12 \mathrm{~d}$ of WL for knotgrass and centipedegrass and $6 \mathrm{~d}$ for spiny mudgrass and seashore paspalum (Fig. 5). At $30 \mathrm{~d}$ of WL, species differed significantly in increased SOD activities, with 1.4 -fold, $87.0 \%, 56.8 \%$, and $11.1 \%$ for knotgrass, spiny mudgrass, seashore paspalum, and centipedegrass, respectively, compared with the control (Fig. 6, Table 1). In roots, the increased SOD activities were observed starting at $12 \mathrm{~d}$ of WL for knotgrass and at $6 \mathrm{~d}$ for spiny mudgrass (Fig. 6). For
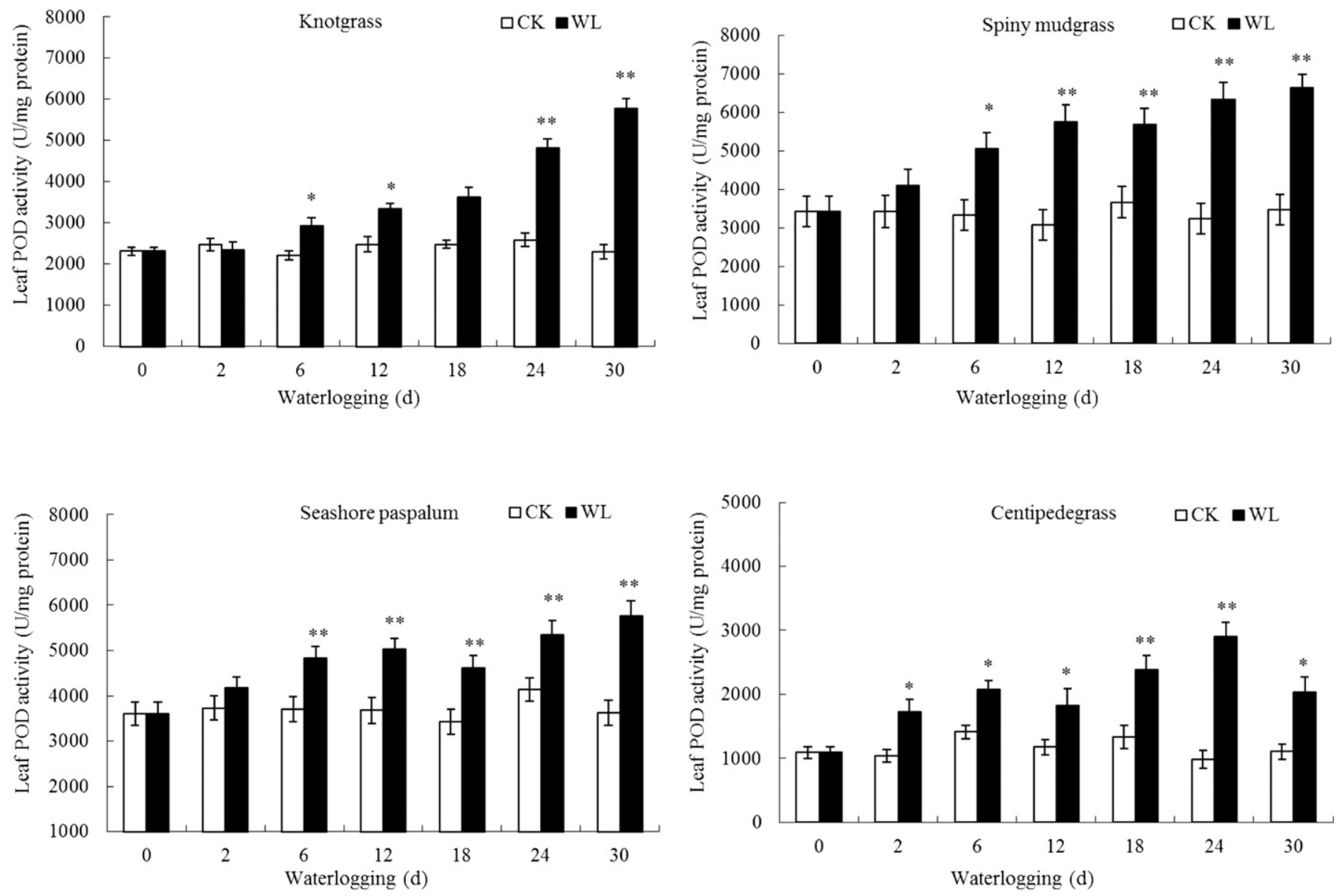

Fig. 7. Leaf activity of peroxidase (POD) as affected by $30 \mathrm{~d}$ of waterlogging in knotgrass, spiny mudgrass, seashore paspalum, and centipedegrass. Comparisons are made between the control (CK) and waterlogging (WL) under each day of treatment for a given species. Values for each date for a given treatment averaged by three replications; * and ** indicate significant differences at $P<0.05$ and $<0.01$, respectively. 
seashore paspalum, the increased SOD activities occurred at $6 \mathrm{~d}$ of WL and lasted for $18 \mathrm{~d}$ (Fig. 6). For E. ophiuroides, the decreased SOD activities were found as early as $2 \mathrm{~d}$ of WL, and SOD activities were then unchanged at $6 \mathrm{~d}$, increased at $12 \mathrm{~d}$, and finally decreased by the end of the stress treatment. At $30 \mathrm{~d}$, the root activities of SOD increased $46.8 \%$ for knotgrass, $39.9 \%$ for spiny mudgrass, $17.7 \%$ for seashore paspalum and were reduced by $37.8 \%$ for centipedegrass (Table 1 ).

Waterlogging increased POD activities, starting at $6 \mathrm{~d}$ of treatment in the leaves and roots for all species except for roots in seashore paspalum, whereas its POD activity increased at $2 \mathrm{~d}$ of WL (Figs. 7 and 8). The increased POD activities were continuously noted in the leaves till the end of the stress. At $30 \mathrm{~d}$, leaf POD activities were 1.5-fold, 91.5\%, $58.8 \%$, and $83.7 \%$ higher than the control for knotgrass, spiny mudgrass, seashore paspalum and centipedegrass, respectively (Table 1, Fig. 7). At $30 \mathrm{~d}$, root POD activities were $76.3 \%, 1.2$-fold, and $45.7 \%$ higher than the control for knotgrass, spiny mudgrass, and seashore paspalum, respectively (Table 1, Fig. 8). There were no changes in POD activities in roots between the control and WL for centipedegrass at $30 \mathrm{~d}$ of treatment (Fig. 8).

The primary reaction of hypoxic-treated roots has been associated with activation of the antioxidative defense system to prevent cells experiencing ROS poisoning (Qi et al., 2014). In the enzymatic defense system, SOD constitutes the first line of defense against ROS by dismutating $\mathrm{O}_{2}^{-}$to $\mathrm{H}_{2} \mathrm{O}_{2}$ (Bowler et al., 1992). Then $\mathrm{H}_{2} \mathrm{O}_{2}$ can be decomposed by POD and/or catalase. The increased, decreased, and unchanged SOD activities were found in different plant species subjected to waterlogging stress (Ahmed et al., 2002; Arbona et al., 2008; Lin et al., 2004; Tan et al., 2010; Wang and Jiang, 2007). In creeping bentgrass, SOD activities in the roots increased under WL in both tolerant and sensitive cultivars, but to a greater extent in the tolerant cultivar (Wang and Jiang, 2007). Similar results were found in the waterlogging tolerant chrysanthemum and sesame compared with the intolerant plants (Wei et al., 2013; Yin et al., 2009). Our results for the four different warm-season grasses in this study were consistent with those findings. Particularly, the higher SOD activities in the roots of the tolerant knotgrass along with the lower SOD activities in the intolerant centipedegrass under a longer period of stress could indicate the importance of SOD in root tolerance to WL. Similarly, the results demonstrated that maintenance of POD activities in the roots were associated with WL tolerance, especially under an extended period of stress. The increased POD activities were also observed in bermudagrass (Cynodon dactylon) under different levels of
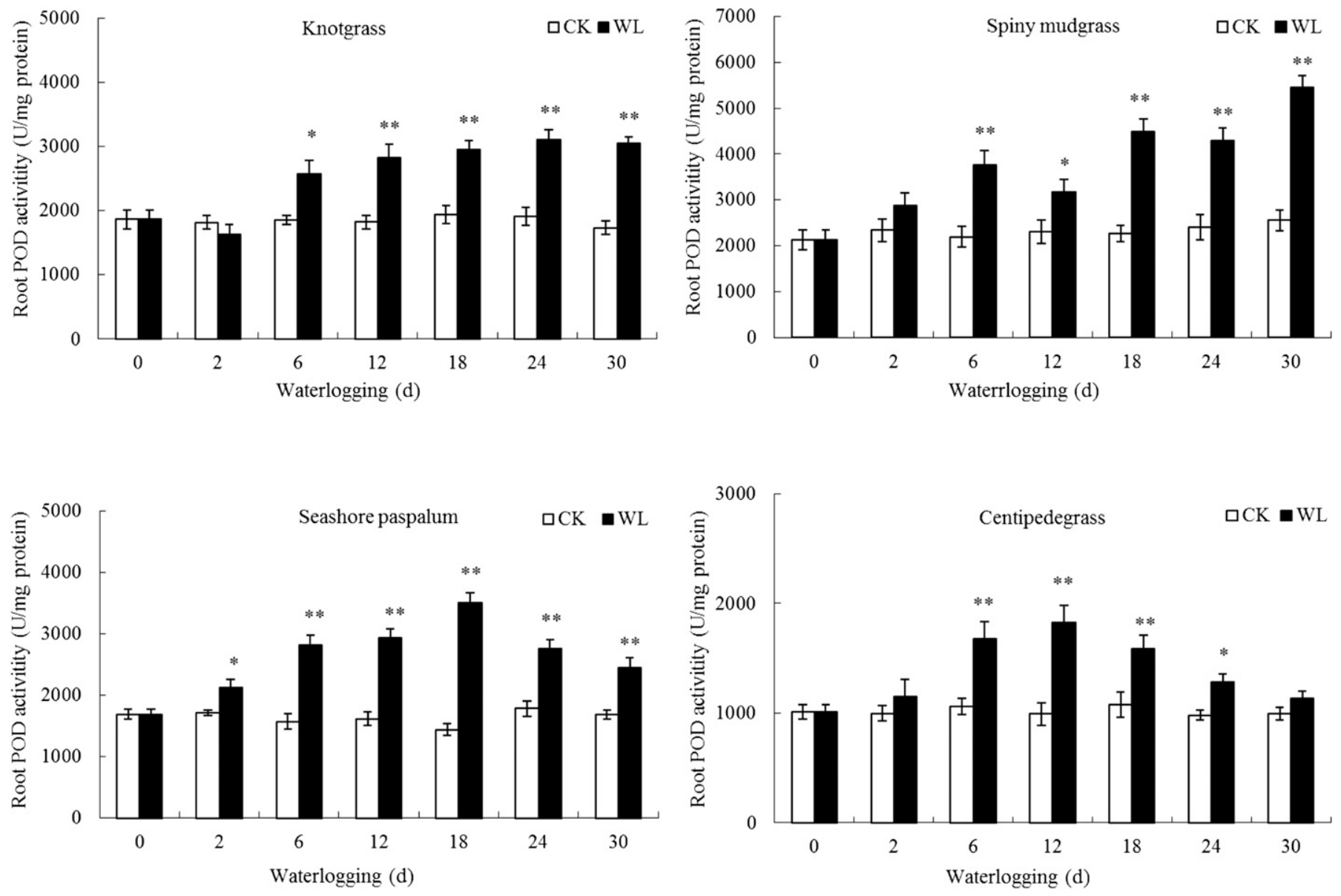

Fig. 8. Root activity of peroxidase (POD) as affected by $30 \mathrm{~d}$ of waterlogging in knotgrass, spiny mudgrass, seashore paspalum, and centipedegrass. Comparisons are made between the control (CK) and waterlogging (WL) under each day of treatment for a given species. Values for each date for a given treatment averaged by three replications; * and ** indicate significant differences at $P<0.05$ and $<0.01$, respectively. 
submergence stress (Tan et al., 2010). However, activities of POD remained unchanged in the roots in response to $21 \mathrm{~d}$ of different depths of WL in both tolerant and intolerant creeping bentgrass cultivars (Wang and Jiang, 2007). It appears that the patterns of antioxidant enzymes under waterlogging may depend on particular species or cultivars and the duration and intensity of stress.

Total SOluble PROTEIN. Waterlogging did not alter TSP concentrations in the leaves of knotgrass throughout the treatment but decreased TSP at 18, 24, and $12 \mathrm{~d}$ of WL for spiny mudgrass, seashore paspalum, and centipedegrass, respectively (Fig. 9). The more reductions in leaf and root TSP were found in seashore paspalum and centipedegrass than in knotgrass and spiny mudgrass by the end of WL treatment (Table 1). At $30 \mathrm{~d}$ of WL, leaf TSP was reduced by $25.0 \%$ for spiny mudgrass, $32.8 \%$ for seashore paspalum, and $36.5 \%$ for centipedegrass, compared with their respective controls (Table 1). In the roots, TSP was unaffected in knotgrass and spiny mudgrass throughout the treatment but was reduced by $32.7 \%$ and $29.7 \%$ at the end of the treatment for seashore paspalum and centipedegrass, respectively (Fig. 10, Table 1).
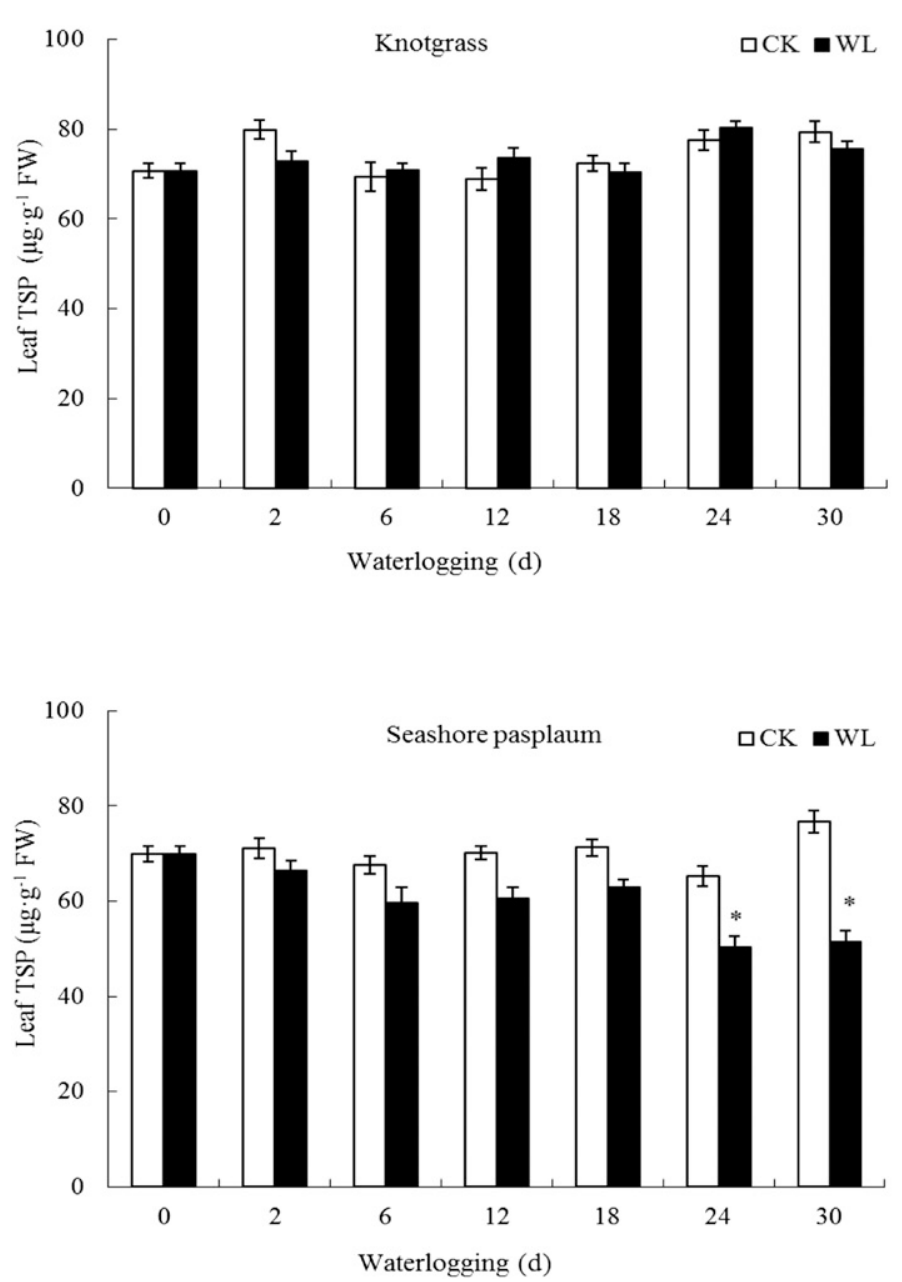

The responses of TSP to flooding stress vary with plant species. The increased, decreased and unchanged TSPs have been reported in plants under WL or submergence (Chen and Qualls, 2003; Kreuzwieser et al., 2002; Mohanty and Ong, 2003). In creeping bentgrass, Jiang and Wang (2006) found that WL reduced root TSP; however, no significant reductions in TSP were observed among three different depths of WL. Reduced TSP was also observed in both leaves and roots in two Dendranthema species subjected to waterlogging (Yin et al., 2010). When red clover (Trifolium repens) was exposed to $14 \mathrm{~d}$ of WL, the sensitive red clover had reductions in leaf soluble protein and Rubisco revealed by protein gel, along with more increased protease activity (Stoychev et al., 2013). The stable TSP in spiny mudgrass and decreased TSP in centipedegrass found in this study provided additional evidence for the role of TSP in WL tolerance in warm-season turfgrass species.

In conclusion, responses of shoots and roots to WL stress varied among four warm-season turfgrass species. Of them, knotgrass showed better WL tolerance, followed by spiny mudgrass and seashore paspalum, while centipedegrass had poor tolerance. Shoot and root biomass was unaffected by WL
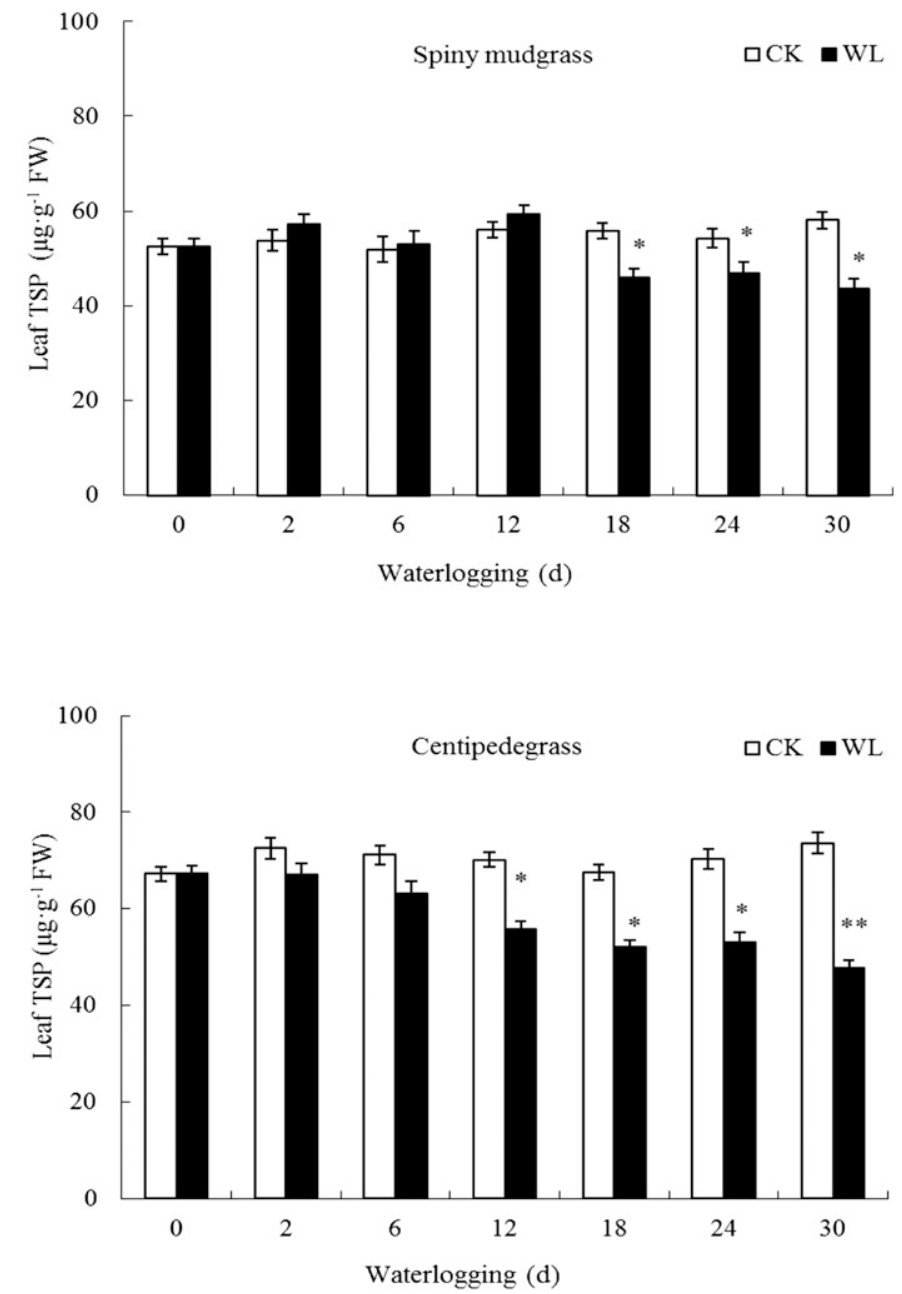

Fig. 9. Leaf total soluble protein concentration (TSP) as affected by $30 \mathrm{~d}$ of waterlogging in knotgrass, spiny mudgrass, seashore paspalum, and centipedegrass. Comparisons are made between the control (CK) and waterlogging (WL) under each day of treatment for a given species. Values for each date for a given treatment averaged by three replications; * and ** indicate significant differences at $P<0.05$ and $<0.01$, respectively. 

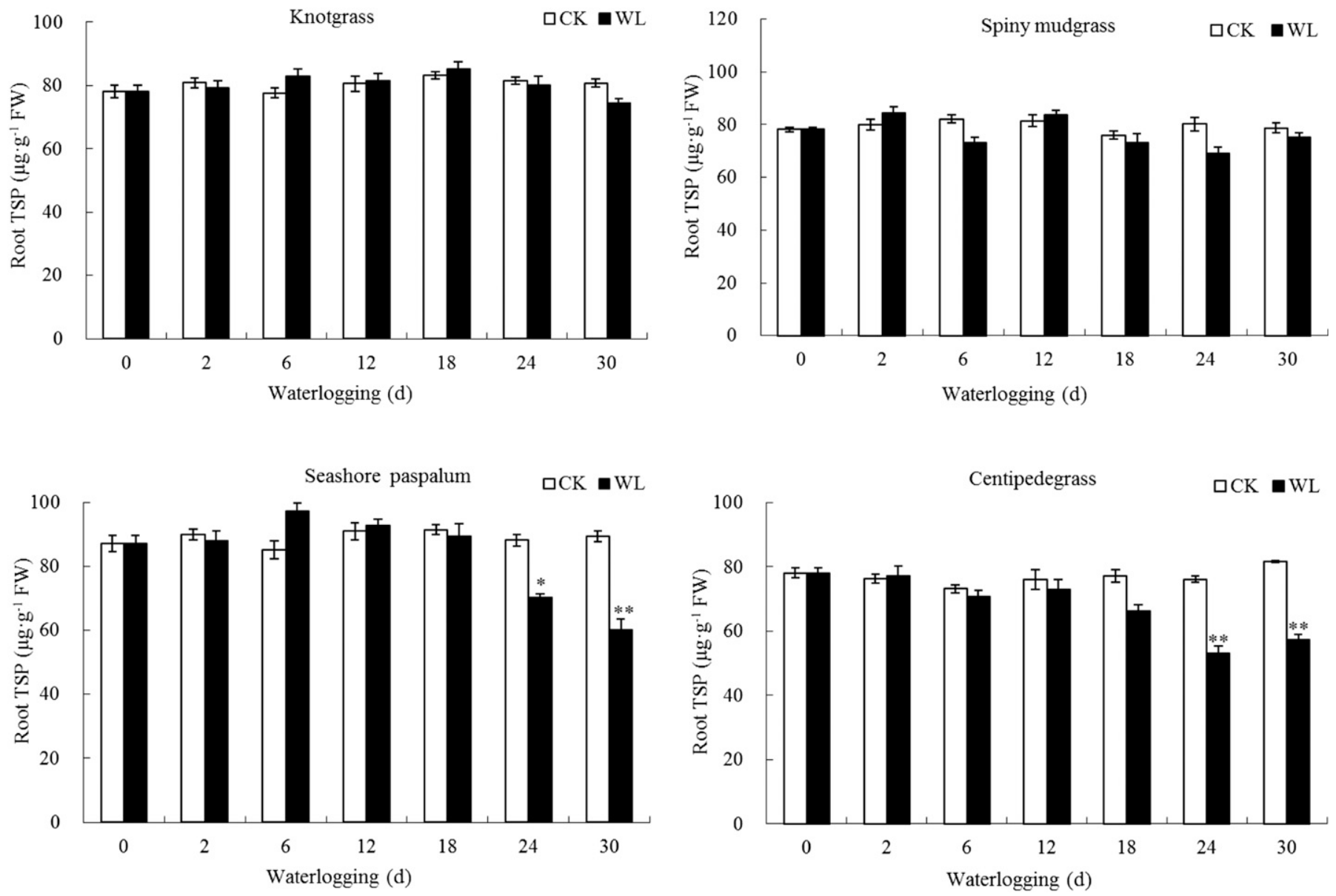

Fig. 10. Root total soluble protein concentration (TSP) as affected by $30 \mathrm{~d}$ of waterlogging in knotgrass, spiny mudgrass, seashore paspalum, and centipedegrass. Comparisons are made between the control (CK) and waterlogging (WL) under each day of treatment for a given species. Values for each date for a given treatment averaged by three replications; * and ** indicate significant differences at $P<0.05$ and $<0.01$, respectively.

in knotgrass and spiny mudgrass and decreased in seashore paspalum and centipedegrass. The higher ROA, the lessincreased root $\mathrm{LDH}$ and $\mathrm{ADH}$ activities as well as maintenance of antioxidant enzyme activity and TSP concentration contributed to WL tolerance of warm-season turfgrass species.

\section{Literature Cited}

Ahmed, S., E. Nawata, M. Hosokawa, Y. Domae, and T. Sakuratani. 2002. Alterations in photosynthesis and some antioxidant enzymatic activities of mungbean subjected to waterlogging. Plant Sci. 163:117-123.

Arbona, V., Z. Hossain, M.F. López-Climent, R.M. Pérez-Clemente, and A. Gómez-Cadenas. 2008. Antioxidant enzymatic activity is linked to water-logging stress tolerance in citrus. Physiol. Plant. 132:452-466.

Armstrong, W. 1979. Aeration in higher plants, p. 225-332. In: H.W. Woolhouse (ed.). Advances in botanical research. Academic Press, London, UK

Bailey-Serres, J. and L.A.C.J. Voesenek. 2008. Flooding stress: Acclimations and genetic diversity. Annu. Rev. Plant Biol. 59:313-319.

Bowler, C., M.V. Montagu, and D. Inze. 1992. Superoxide dismutase and stress tolerance. Annu. Rev. Plant Physiol. Plant Mol. Biol. 43:83-116.
Bradford, M.M. 1976. A rapid and sensitive method for the quantitation of microgram quantities of protein utilizing the principle of protein-dye binding. Anal. Biochem. 72:248-254.

Chen, H. and R.G. Qualls. 2003. Anaerobic metabolism in roots of the seedlings of invasive exotic Lepidium latifolium. Environ. Exp. Bot. 50:29-40.

Colmer, T.D. and L.A.C.J. Voesenek. 2009. Flooding tolerance: Suites of plant traits in variable environments. Funct. Plant Biol. 36:665681.

Drew, M.C. 1983. Plant injury and adaptation to oxygen deficiency in the root environment: A review. Plant Soil 75:179-199.

Drew, M.C. 1997. Oxygen deficiency and root metabolism: Injury and acclimation under hypoxia and anoxia. Annu. Rev. Plant Physiol. Plant Mol. Biol. 48:223-250.

Gao, Y., J. Zong, F. Meng, J. Chen, R. Shuang, and J. Liu. 2014. Evaluating submergence tolerance of different warm-season turfgrass cultivars. Acta Agrestia Sinica 22:1020-1030.

Giannopolities, C.N. and S.K. Rise. 1977. Superoxide dismutases. I. Occurrence in higher plants. Plant Physiol. 59:304-309.

Ismond, K.P., R. Dolferus, M. De Pauw, E.S. Dennis, and A.G. Good. 2003. Enhanced low oxygen survival in Arabidopsis through increased metabolic flux in the fermentative pathway. Plant Physiol. 132:1292-1302.

Jackson, M.B. 1985. Ethylene and responses of plants to soil waterlogging and submergence. Annu. Rev. Plant Physiol. 36:145-174.

Jain, V., N.K. Singla, S. Jain, and G. Kaushalya. 2010. Activities of enzymes of fermentation pathways in the leaves and roots of 
contrasting cultivars of sorghum (Sorghum bicolor L.) during flooding. Physiol. Mol. Biol. Plants 16:241-247.

Jiang, Y. and K. Wang. 2006. Growth, physiological and anatomical responses of creeping bentgrass cultivars to different depths of waterlogging. Crop Sci. 46:2420-2426.

Kato, H. 2000. Abscisic acid and hypoxic induction of anoxia tolerance in roots of lettuce seedlings. J. Expt. Bot. 51:1939-1944.

Kato-Noguchi, H. and M. Morokuma. 2007. Ethanolic fermentation and anoxia tolerance in four rice cultivars. J. Plant Physiol. 164:168-173. Kozlowski, T.T. 1984. Flooding and plant growth. Academic Press, London, UK.

Kreuzwieser, J., S. Furniss, and H. Rennenberg. 2002. Impact of waterlogging on the $\mathrm{N}$-metabolism of flood tolerant and non-tolerant tree species. Plant Cell Environ. 25:1039-1049.

Li, H. 2000. Principle and technology of plant physiology and biochemistry experiment. Higher Educ. Press, Beijing, P.R. China.

Lin, K.H., C.C. Weng, H.F. Loa, and J.T. Chen. 2004. Study of the root antioxidative system of tomatoes and eggplants under waterlogged conditions. Plant Sci. 167:355-365.

Mittler, R. 2002. Oxidative stress, antioxidants and stress tolerance. Trends Plant Sci. 7:405-410.

Mohanty, B. and B.L. Ong. 2003. Contrasting effects of submergence in light and dark on pyruvate decarboxylase activity in roots of rice lines differing in submergence tolerance. Ann. Bot. (Lond.) 91:291300.

Ota, Y. 1970. Diagnostic method for measurement of root activity in rice plant. Jpn. Agr. Res. Qrtly. 5:1-6.

Pearson, C.H. and M.B. Kirkham. 1981. Water relations of wheat cultivars grown with cadmium. J. Plant Nutr. 3:309-318.

Qi, B., Y. Yang, Y. Yin, M. Xu, and H. Li. 2014. De novo sequencing, assembly, and analysis of the Taxodium 'Zhongshansa' roots and shoots transcriptome in response to short-term waterlogging. BMC Plant Biol. 14:201.

Richard, B., S. Aschi-Smiti, I. Gharbi, and R. Brouquisse. 2006. Cellular and molecular mechanism of plant tolerance to waterlogging, p. 177-208. In: B. Huang (ed.). Plant-environment interaction. CRC Press, Boca Raton, FL.

Roberts, J.K.M., K. Chang, C. Webster, J. Callis, and V. Walbot. 1989. Dependence of ethanolic fermentation, cytoplasmic $\mathrm{pH}$ regulation, and viability on the activity of alcohol dehydrogenase in hypoxic maize root tips. Plant Physiol. 89:1275-1278.

Stoychev, V., L. Simova-Stoilova, I. Vaseva, A. Kostadinova, R. Nenkova, U. Feller, and K. Demirevska. 2013. Protein changes and proteolytic degradation in red and white clover plants subjected to waterlogging. Acta Physiol. Plant. 35:1925-1932.

Tan, S., M. Zhu, and Q. Zhang. 2010. Physiological responses of bermudagrass (Cynodon dactylon) to submergence. Acta Physiol. Plant. 32:133-140.

Wang, K. and Y. Jiang. 2007. Waterlogging tolerance of kentucky bluegrass cultivars. HortScience 42:386-390.

Wang, K., S. Bian, and Y. Jiang. 2009. Anaerobic metabolism of roots in kentucky bluegrass in response to short term waterlogging alone and in combination with high temperatures. Plant Soil 314:221-229.

Wei, W., D. Li, L. Wang, X. Ding, Y. Zhang, Y. Gao, and X. Zhang. 2013. Morpho-anatomical and physiological responses to waterlogging of sesame (Sesamum indicum L.). Plant Sci. 208:102-111.

Ye, Y., F.Y. Nora Tam, Y.S. Wong, and C.Y. Lu. 2003. Growth and physiological responses of two mangrove species (Bruguiera gymnorrhiza and Kandelia candel) to waterlogging. Environ. Exp. Bot. 49:209-221.

Yin, D., S. Chen, F. Chen, Z. Guan, and W. Fang. 2009. Morphological and physiological responses of two chrysanthemum cultivars differing in their tolerance to waterlogging. Environ. Exp. Bot. 67:87-93.

Yin, D., S. Chen, F. Chen, Z. Guan, and W. Fang. 2010. Morphoanatomical and physiological responses of two Dendranthema species to waterlogging. Environ. Exp. Bot. 68:122-130.

Yu, X., N. Luo, J. Yan, J. Tang, S. Liu, and Y. Jiang. 2012. Differential growth response and carbohydrate metabolism of global collection of perennial ryegrass accessions to submergence and recovery following de-submergence. J. Plant Physiol. 169:1040-1049. 